\section{Connecticut Nursery and Landscape Industry Preferences for Solutions to the Sale and Use of Invasive Plants}

\author{
James A. Gagliardi ${ }^{1}$ and Mark H. Brand ${ }^{2,3}$
}

ADDITIONAL INDEX WORDs. ornamental plants, survey, nursery crops, noninvasive

SumMARY. Survey data from 114 members (42\% response rate) of the Connecticut Nursery and Landscape Association were analyzed to evaluate preferences for different potential solutions to reduce the annual sale of billions of dollars of invasive ornamental plants. The majority of respondents accurately identified key invasive plant characteristics, considered themselves to be knowledgeable about invasive plants, and cited trade journals and professional organizations as their sources of invasive plant information. Although industry members generally considered norway maple (Acer platanoides), japanese barberry (Berberis thunbergii), and winged euonymus (Enonymus alatus) to be invasive, only $14.5 \%$ and $8.1 \%$, respectively, considered the emerging invasive species japanese silver grass (Miscanthus sinensis) and butterfly bush (Buddleja davidii) to be invasive. In comparing different approaches to reducing the sale of invasive ornamental plants, strong support was expressed for marketing noninvasive alternative plants (mean rank of 2.5) and for development of genetically altered sterile forms of invasive ornamentals (mean rank of 2.9; on a scale from $1=$ most favorable to $6=$ least favorable). Respondents strongly disfavored taxation as a method of reducing invasive plants sales (mean rank of 5.0) even if proceeds were directed toward invasive plant control and research. Plant bans (mean rank of 4.1) were also an unpopular choice for economically important crops, and respondents desired provisions for cultivars with reduced invasive risk to be included in plant bans. To foster maximum green industry participation in invasive plant control efforts, future directions should focus on creation of sterile forms of popular landscape plants, identification of consumer preference for noninvasive alternatives, and development of strong consumer education programs.

$\mathrm{I}$ nvasive species pose the second greatest threat to natural ecosystems and are surpassed only by habitat destruction as a threat to global biodiversity (Bir, 2000; Morin, 1999; Wilcove et al., 1998). Nonnative plants that establish selfsustaining populations in natural landscapes can alter the composition of native plant communities through physical displacement (Webb et al., 2000; Woods, 1993) and interspecific hybridization (Pooler et al., 2002). These perturbations have cascading effects on native herbivores (Tallamy, 2001 ), the physical and chemical properties of soil (Ehrenfeld et al., 2001; Heneghan et al., 2002), and on

\footnotetext{
Department of Plant Science, Unit-4067, University of Connecticut, Storrs, CT 06269-4067.

This research was supported by an Office of Undergraduate Research Grant from the University of Connecticut.

This article is based on an Honors Thesis submitted as part of the requirements for completion of an Honors Undergraduate degree.

${ }^{1}$ Undergraduate Honors student.

${ }^{2}$ Professor, Ornamental Horticulture

${ }^{3}$ Corresponding author. E-mail: mark.brand@uconn.edu
}

ecosystem processes such as fire and hydrology regimes and nutrient cycling (Gordon, 1998; Vitousek et al., 1996). These impacts, coupled with the economic costs of management and control (Pimentel et al., 2000), emphasize the importance of developing successful solutions to the invasive plant issue.

Many plants of horticultural interest are found on the lists of invasive species compiled by state and regional Exotic Pest Plant Councils and native plant societies (Bell et al., 2003). According to Reichard and White (2001), most woody plants that are considered "invasive" were originally introduced for horticultural purposes. They found that more than $80 \%$ of the 235 woody plant species widely considered invasive had been used in landscaping or for ornamental purposes. Of the 78 plants considered most invasive in California, 41 were propagated by nurseries for use as ornamentals (Bossard et al., 2000). Similarly, Randall and Marinelli (1996) describe 80 plants that are considered invasive in a variety of regions throughout the United States, all of which are currently or were previously used as landscape plants.

The U.S. nursery and greenhouse industry is an important part of the national economy, producing $\$ 15.7$ billion in wholesale receipts during 2004 (U.S. Department of Agriculture, 2005). Ornamental plant sales are driven by consumer demand for novel, often nonnative species or cultivars (Brand and Leonard, 2001). These market forces make it difficult for growers and landscapers to change their approach to the production and use of invasive species. Recently, Massachusetts and New Hampshire have passed legislation that prohibits the importation, sale, trade, distribution, and related activities of several important ornamental plants (Massachusetts Department of Agricultural Resources, 2006; New Hampshire Department of Agriculture, Markets and Food, 2004). Although plant bans may be part of the solution to the complex problem of invasive ornamental plants, it is likely that a resolution to the problem will require a multifaceted approach.

Increasingly, the ornamental industry is becoming more proactive on the issue of invasive plants. There is a growing recognition of the problem and a sense of ecologic responsibility, but also a strong preference for voluntary initiatives over legislation that would restrict the introduction, propagation, use, and sale of plants (Baskin, 2002; Harrington et al., 2003). Nursery and landscape representatives are working together with experts representing botanical gardens, government agencies, landscape architects, conservation organizations, and universities to develop and endorse a set of Voluntary Codes of Conduct for Nursery Professionals to follow when dealing with invasive plant issues (Baskin, 2002). Although plant professionals are clearly participating in the development of invasive ornamental plant solutions, they remain concerned about several issues: 1) how invasive plants are defined; 2 ) lack of regulation at a regional rather than national level; 3) lack of objective, science-based data; 4) insufficient recognition of cultivar differences within a species; 5 ) incomplete separation of the invasive plant issue from native plant use; and 6 ) the need to minimize economic disruption to the 
nursery industry (American Nurseryman, 1999; Harrington et al., 2003; Lehrer et al., 2006; Miller, 2005). Effective solutions to the invasive ornamental plant problem will require full participation by the nursery, landscape, and greenhouse industries. Invasive ornamental plant control measures developed without consideration for the ornamental plant industry perspective will have reduced effectiveness and probable economic impacts. A better understanding of the opinions of the green industry toward different approaches to ornamental invasive plant control is needed to develop effective programs aimed at reducing the impact of invasive ornamental plants. This survey focuses on the opinions related to ornamental invasive plants by members of the Connecticut nursery and landscape industry. Debate about ornamental invasive plants has been especially intense in Connecticut, and the findings presented here should be useful to those in other regions who are just beginning to confront the invasive plant issue.

\section{Materials and methods}

A survey was developed to obtain information on the attitudes and opinions of Connecticut nursery and landscape industry members on invasive ornamental plants and their sale. The first part of the survey determined each respondent's personal views about their own invasive plant knowledge, invasive plant regulation, sources of invasive plant information, and the invasiveness of specific ornamental crops. The core of the survey asked for opinions regarding potential solutions to the sale of invasive ornamental plants, including statewide bans of invasive plants, voluntary removal of invasive plants from inventories, use of notification labels on plants to inform about invasive characteristics, promotion of noninvasive alternatives, taxation of invasive plants sold, and acceptability of sterile, genetically altered invasive plants. Descriptive information was also collected from each respondent to determine the types of businesses and individuals that participated in the survey.

In total, 39 closed-ended questions were asked. Additional space was provided for participants to further express opinions beyond the scope of the supplied questions. Most questions were measured on a 5-point Likert scale (Likert, 1932) $(5=$ strongly agree, $4=$ agree, $3=$ unsure, 2 = disagree, 1 = strongly disagree) . One question required respondents to rank a list of selections from $1=$ most favorable to $6=$ least favorable. Other questions required respondents to check appropriate choices or fill in a blank. In responding to the survey, people were asked to define invasive plants by the criteria set forth by Connecticut Public Act 03-136 (Connecticut Invasive Plants Council, 2004).

The survey was mailed to 270 members of the Connecticut Nursery and Landscape Association (CNLA) who had Connecticut mailing addresses and the potential to work with invasive plants in their business. The initial mailing was done in Sept. 2005 and included a copy of the survey, a cover letter, and a postage-paid return envelope. Five weeks after the initial mailing, e-mail reminders were sent to survey recipients who had not returned their surveys. The e-mail asked for the return of the original survey or allowed recipients to request a new survey be mailed. In March 2006, surveys were mailed to 50 recipients who had still not returned a completed survey in an attempt to increase the response rate.

Survey data were analyzed using the univariate procedure of SAS (PC SAS version 8.02; SAS Institute, Cary, N.C.). Responses with missing information for particular variables were excluded on an analysis-by-analysis basis. This caused slight variation in the effective sample size for each analysis. Differences between category or rank means were determined using multiple comparisons for proportions and the Tukey test (Williams and LeBlanc, 1995).

\section{Results and discussion}

RESPONDENT PROFILE. The survey was mailed to 270 members of the CNLA and returned by 114 members to yield a $42 \%$ survey return rate. Many of the respondents were leaders in Connecticut's green industry. Over $77 \%$ of respondents owned a business, and most others worked as supervisors or managers (Table 1 ). The business focus of half of the respondents was landscape care, design, or installation. Although $29.7 \%$ consid-
Table 1. Selected characteristics of surveyed Connecticut Nursery and Landscape Association members.

\begin{tabular}{lc}
\hline $\begin{array}{l}\text { Respondent } \\
\text { characteristic }\end{array}$ & $\begin{array}{c}\text { Respondents } \\
(\%)\end{array}$ \\
\hline $\begin{array}{l}\text { Business focus of employer } \\
\quad \text { Landscaper (care, }\end{array}$ & 50.0 \\
$\quad$ installation, or design) & \\
Retail or garden center & 29.7 \\
$\quad$ Wholesale or grower & 20.3 \\
Employment position & \\
Owner & 77.5 \\
Supervisor or manager & 20.7 \\
Other & 1.8 \\
Business location & \\
$\quad$ Rural & 37.5 \\
Suburban & 54.2 \\
Urban & 8.3 \\
Yearly gross income of & \\
$\quad$ employer & \\
\$0-150,000 & 15.4 \\
\$150,001-1,000,000 & 43.3 \\
> \$1,000,000 & 41.3 \\
Employees at peak & \\
$\quad$ season (no.) & \\
1-10 & \\
11-50 & \\
$>50$ & 44.8 \\
\hline
\end{tabular}

ered their business to be a retail outlet or a garden center, $20.3 \%$ classified themselves as wholesale growers. The locations of $91.7 \%$ of the businesses surveyed were in suburban or rural areas of the state. The yearly gross income for $43.3 \%$ of the businesses surveyed fell between $\$ 150,001$ and $\$ 1$ million, and $41.3 \%$ grossed more than $\$ 1$ million. Over half of the businesses surveyed employ more than 10 workers during their peak season.

When asked if they consider themselves knowledgeable about invasive plants, $80.4 \%$ of CNLA members agreed or strongly agreed (Table 2 ). A recent survey found that $81.5 \%$ of gardening consumers were aware that nonnative plants were used in the landscape and that these plants may be invasive in natural areas (Kelley et al., 2006). Most CNLA members cited trade journals and articles and professional organizations as their main sources of invasive plant knowledge (Table 3). Information about invasives should, therefore, be distributed to the industry through these forums. In contrast, a large percentage of gardeners learn about invasive plants from television and newspapers/magazines/books (Kelley et al., 2006). 
Table 2. Connecticut Nursery and Landscape Association member opinion of their personal invasive plant knowledge and amount of invasive plant education being done.

\begin{tabular}{|c|c|c|c|c|c|c|}
\hline & \multicolumn{5}{|c|}{ Respondents selecting each rank (\%) } & \multirow[b]{2}{*}{ Mean } \\
\hline & $\begin{array}{l}\text { Strongly } \\
\text { disagree } \\
1\end{array}$ & 2 & 3 & 4 & $\begin{array}{l}\text { Strongly } \\
\text { agree } \\
5\end{array}$ & \\
\hline $\begin{array}{l}\text { Consider themselves } \\
\text { knowledgeable about } \\
\text { invasive plants }\end{array}$ & $2.8 b^{z}$ & $4.7 \mathrm{~b}$ & $12.1 \mathrm{~b}$ & $50.5 \mathrm{a}$ & $29.9 \mathrm{a}$ & 4.0 \\
\hline $\begin{array}{l}\text { Believe sufficient invasive } \\
\text { plants education occurs }\end{array}$ & $12.5 \mathrm{bc}$ & $26.8 \mathrm{ab}$ & $28.6 \mathrm{a}$ & $22.3 \mathrm{abc}$ & $9.8 \mathrm{c}$ & 2.9 \\
\hline
\end{tabular}

${ }^{\mathrm{z}}$ Means within a row followed by the same letter are not significantly different according to multiple comparisons for proportions and the Tukey test at $P \leq 0.05$.

Table 3. Connecticut Nursery and Landscape Association member sources of invasive plant information, preference for invasive plant regulatory organization and ranking of characteristics of invasive plants.

\begin{tabular}{lc}
\hline & $\begin{array}{c}\text { Respondents selecting } \\
\text { each choice (\%) }\end{array}$ \\
\hline Source of invasive plant knowledge & \\
Trade journals and articles & $86.8 \mathrm{a}$ \\
Professional organizations & $81.6 \mathrm{a}$ \\
Schools or colleges & $46.5 \mathrm{~b}$ \\
Government programs & $26.3 \mathrm{c}$ \\
News media & $26.3 \mathrm{c}$ \\
Organization that should be in charge of regulation & \\
The state government & $63.8 \mathrm{a}$ \\
Individual business owners & $17.3 \mathrm{~b}$ \\
Federal government & $17.3 \mathrm{~b}$ \\
Town governments & $1.6 \mathrm{c}$ \\
Characteristics of invasive plants & \\
Grow and proliferate aggressively & $78.9 \mathrm{a}$ \\
Produce high numbers of offspring & $74.6 \mathrm{a}$ \\
Threaten biologic diversity & $69.3 \mathrm{ab}$ \\
Persist without cultivation & $64.0 \mathrm{ab}$ \\
Harm other plants & $62.3 \mathrm{abc}$ \\
Harm the environment & $55.3 \mathrm{bc}$ \\
Nonindigenous & $43.0 \mathrm{c}$ \\
Found only in disturbed areas & $7.9 \mathrm{~d}$ \\
\hline
\end{tabular}

${ }^{2}$ Mean separation within subgroups in the column by multiple comparisons for proportions and the Tukey test at $P \leq 0.05$.

Regulation OF INVASIVE PLANT SALES. A majority $(63.8 \%)$ of survey participants felt that the state government should be in charge of invasive plant regulation (Table 3 ). In a survey of 76 American Nursery and Landscape Association (ANLA) members, respondents felt that state government $(58 \%)$, trade organizations $(47 \%)$, and the federal government $(43 \%)$ should have responsibility for invasive plant regulation (Hall, 2000). In contrast, consumers selected nurseries and greenhouses, universities, and nursery associations as the top three choices of groups that should test and report plant invasiveness (Kelley et al., 2006). like CNLA members, ANLA members identified invasive plants as those with aggressive growth, persistence in the environment, and the ability to harm other plants and threaten biodiversity. Gardening consumers also considered the ability to grow aggressively and produce viable seeds that germinate rapidly to be important characteristics of an invasive plant species (Kelley et al., 2006).

SALE AND USE OF KNOWN INVASIVE PLANTS. Half or more of the respondents reported working with norway maple, japanese barberry, and winged euonymus at their place of employment, although all three species are categorized as invasive on Connecticut's Invasive Plant List (Connecticut Invasive Plants Council, 2004) (Table 4). Sixty-eight percent of respondents reported japanese silver grass, listed as potentially invasive in Connecticut, as a plant they worked with at their place of employment. Butterfly bush, which is not categorized as invasive or potentially invasive in Connecticut, but is exhibiting invasive tendencies in slightly milder areas (Anisko and Im, 2001), was in use at $92.1 \%$ of businesses. When asked which of these plants they considered invasive, $59.3 \%$ said winged euonymus is invasive, $54.0 \%$ considered japanese barberry invasive and $50.9 \%$ thought norway maple is invasive. Species that have more recently begun to show invasive tendencies were considered to be invasive by only a small percentage of CNLA members (14.5\% for Japanese silver grass and $8.1 \%$ for butterfly bush). However, there was a great amount of uncertainty for japanese silver grass, with $32.7 \%$ of respondents reporting that they were unsure about the invasiveness of the plant. Members of the green industry appear to have a better grasp of landscape plant invasiveness than garden consumers. Gardeners only correctly identified norway maple as invasive $20.2 \%$ of the time and japanese barberry as invasive $10.4 \%$ of the time (Kelley et al., 2006). If gardeners are unaware of the invasive nature of certain landscape plants, they will continue to use them in their landscapes. Because gardener demand for landscape plants plays a major role in what wholesale producers must propagate and grow for sale, increased education efforts to teach landscape 
Table 4. Percentage of Connecticut Nursery and Landscape Association members who work with or use plants considered to be invasive or potentially invasive in Connecticut and whether the respondents consider them invasive.

\begin{tabular}{lrrr}
\hline & \multicolumn{3}{c}{ Respondents selecting each choice (\%) } \\
\cline { 2 - 4 } & Yes & No & Unsure \\
\hline Use the plant at work & & & \\
Norway maple & 49.1 & 50.9 & 0 \\
Japanese barberry & 66.4 & 33.6 & 0 \\
Butterfly bush & 92.1 & 7.9 & 0 \\
Winged euonymus & 64.0 & 36.0 & 1.8 \\
Japanese silver grass & 68.1 & 30.1 & \\
Consider the plant invasive & & & 3.5 \\
Norway maple & 50.9 & 45.6 & 13.3 \\
Japanese barberry & 54.0 & 32.7 & 7.9 \\
Butterfly bush & 8.1 & 82.0 & 32.7 \\
Winged euonymus & 59.3 & 33.6 & 52.7 \\
Japanese silver grass & 14.5 & & \\
\hline
\end{tabular}

consumers about invasive plants should result in reduced demand for, and production of, invasive species. It seems that CNLA members are cognizant of this situation, because only $32.1 \%$ of CNLA respondents agreed or strongly agreed with the statement that a sufficient amount of education is being done about invasive plants (Table 2).

Methods of Invasive plant REgulation. Possible methods for handling the sale of invasive plants were investigated as part of the survey. Some of the strongest opinions on the survey were voiced in reference to the banning of invasive plants. When asked if invasive plants that are economically unimportant should be banned, $76.3 \%$ of the respondents were supportive and half strongly agreed to the use of plant bans in this case (Table 5). However, when asked if economically important invasive plants should be banned, only $32.8 \%$ of CNLA members were in favor of plant bans. Furthermore, $33.6 \%$ of the respondents strongly disfavored bans of economically important invasive plants, whereas only $7.9 \%$ strongly disfavored bans of economically unimportant plants. Clearly, economic factors related to plant sales determine whether nursery industry members are supportive of invasive plant bans. Kelley et al. (2006) found that $41 \%$ of gardening consumers felt that local, state, or federal laws should be passed to prevent the sale of nonnative invasive plants in their area. CNLA members did not seem to be sure that bans would be effective in reducing invasive plant populations, because responses were equally dis- tributed across all levels of agreement (Table 5). and landscape industry, environmental groups, researchers, municipalities, and the public have participated in a great deal of debate about how to treat cultivars of plants, especially when considering bans of invasive species. Often, environmental groups prefer bans that include all genotypes of an invasive species, whereas nursery and landscape industry members are more open to treating some cultivars differently than the species. The majority of CNLA members either agreed $(24.6 \%)$ or strongly agreed $(60.5 \%)$ that there should be provisions made in invasive plant bans for cultivars with reduced invasive risk (Table 5). Apparently, even gardening consumers differentiate between cultivars and the species, because less that one-fourth of gardeners felt that if a species was considered invasive, then all cultivars of that species should be considered invasive (Kelley et al., 2006).

CNLA members showed some preference for self-regulation over state mandated bans. When questioned if they were willing to voluntarily remove invasive plants from their stock, only $26.6 \%$ of respondents disagreed or strongly disagreed and over $50 \%$ agreed or strongly agreed (Table 5). A willingness to voluntarily remove a small, select group of invasive plants was also noted among $60.5 \%$ of surveyed ANLA members (Hall, 2000). Some hesitation to voluntarily remove invasive plants from inventories may come from the widely held belief that
Self-regulation. The nursery customers will go elsewhere to buy invasive plants if they are not found at one particular retail establishment. Over half of the CNLA members thought that consumers would seek to purchase invasive plants from another business if they did not carry them in their inventory. Another $28.9 \%$ of respondents were unsure what the consumer would do. Counter to the beliefs of CNLA members, a survey of consumers found that $92 \%$ of participants said they would definitely not seek out an invasive species from another vendor (Reichard and White, 2001). For voluntary removal of invasive plants to be adopted on a widespread basis as a control measure for invasive ornamentals, plant professionals will have to develop much greater confidence that doing so will not lead to loss of sales.

VOLUNTARY PROGRAMs. Voluntary removal of invasive plants may be more appealing to the nursery and landscape industry if there is a way for businesses to market their environmentally friendly actions to positively affect sales. Fifty-five percent of respondents felt that a formal program that classifies businesses as "environmentally friendly" if they do not sell invasive plants could be useful to promote sales at their business (Table $5)$. Furthermore, at least half of the respondents felt that such a program would be effective in reducing the sale of invasive plants.

LABELING INVASIVE PLANTS. As an alternative to plant bans and voluntary removal, the use of labels on plants to warn consumers of their invasive potential would allow businesses to continue to sell invasive plants while making the public more educated about their purchase. CNLA members were overwhelmingly willing to voluntarily use labels on invasive plants, with only $16.6 \%$ of the CLNA members expressing unwillingness to do so (Table 5). Support was even relatively strong for a state-mandated labeling program. Hall (2000) also found that only 22\% of plant professionals would not use warning labels that specified the regions where a plant is considered invasive. Although there was little objection to labels on plants that are currently considered invasive, the labeling of potentially invasive plants received a much lower ranking (Table $5)$. Over $50 \%$ of CNLA members had 
Table 5. Connecticut Nursery and Landscape Association member opinions on proposed methods for handling the sale of ornamentally important invasive plants.

\begin{tabular}{|c|c|c|c|c|c|c|}
\hline \multirow[b]{2}{*}{ Method } & \multicolumn{5}{|c|}{ Respondents selecting each rank (\%) } & \multirow[b]{2}{*}{$\begin{array}{c}\text { Mean } \\
\text { rank }\end{array}$} \\
\hline & $\begin{array}{c}\text { Strongly } \\
\text { disagree } \\
1 \\
\end{array}$ & 2 & 3 & 4 & $\begin{array}{c}\text { Strongly } \\
\text { agree } \\
5 \\
\end{array}$ & \\
\hline \multicolumn{7}{|l|}{ Banning the use of invasive plants } \\
\hline Support statewide bans of economically unimportant invasive plants & $7.9 c^{z}$ & $7.0 \mathrm{c}$ & $8.8 \mathrm{c}$ & $26.3 \mathrm{~b}$ & $50.0 \mathrm{a}$ & 4.0 \\
\hline Support statewide bans of economically important invasive plants & $33.6 \mathrm{a}$ & $19.5 \mathrm{ab}$ & $14.1 \mathrm{~b}$ & $14.1 \mathrm{~b}$ & $18.7 \mathrm{ab}$ & 2.6 \\
\hline Provisions are needed for cultivars with reduced invasive risk & $3.5 \mathrm{c}$ & $2.6 \mathrm{c}$ & $8.8 \mathrm{c}$ & $24.6 \mathrm{~b}$ & $60.5 \mathrm{a}$ & 4.4 \\
\hline $\begin{array}{l}\text { Statewide bans are effective in reducing invasive plants populations } \\
\text { Voluntary removal of invasive plants }\end{array}$ & $18.4 \mathrm{a}$ & $18.3 \mathrm{a}$ & $18.4 \mathrm{a}$ & $22.0 \mathrm{a}$ & 22.9 a & 3.1 \\
\hline Willing to voluntarily remove invasive plants from stock & $11.0 \mathrm{~b}$ & $15.6 \mathrm{ab}$ & $20.2 \mathrm{ab}$ & $24.8 \mathrm{ab}$ & $28.4 \mathrm{a}$ & 3.4 \\
\hline $\begin{array}{l}\text { Consumers will go elsewhere to buy invasive plants if I remove them } \\
\text { from my stock }\end{array}$ & $9.9 \mathrm{~b}$ & $9.0 \mathrm{~b}$ & 28.9 a & 27.9 a & $24.3 \mathrm{a}$ & 3.5 \\
\hline $\begin{array}{l}\text { An "environmentally friendly" classification would be useful for } \\
\text { self-promotion }\end{array}$ & $13.2 \mathrm{bc}$ & $7.0 \mathrm{c}$ & $24.6 \mathrm{ab}$ & $28.9 \mathrm{a}$ & $26.3 \mathrm{ab}$ & 3.5 \\
\hline $\begin{array}{l}\text { An "environmentally friendly" classification would decrease the sale } \\
\text { of invasive plants }\end{array}$ & $7.0 \mathrm{~b}$ & $7.9 \mathrm{~b}$ & $34.2 \mathrm{a}$ & $29.0 \mathrm{a}$ & $21.9 \mathrm{a}$ & 3.5 \\
\hline \multicolumn{7}{|l|}{ Invasive plant notification labels } \\
\hline Would voluntarily use notification la & $6.3 \mathrm{~b}$ & $9.8 \mathrm{~b}$ & $25.0 \mathrm{a}$ & $28.6 \mathrm{a}$ & $30.4 \mathrm{a}$ & 3.7 \\
\hline Support a state-mandated program $\mathrm{rc}$ & $12.5 \mathrm{~b}$ & $8.9 \mathrm{~b}$ & $18.8 \mathrm{ab}$ & $30.4 \mathrm{a}$ & $29.5 \mathrm{a}$ & 3.6 \\
\hline $\begin{array}{l}\text { Support a state-mandated program requiring labeling of potentially } \\
\text { invasive plants }\end{array}$ & $33.3 \mathrm{a}$ & $21.9 \mathrm{ab}$ & $15.8 \mathrm{~b}$ & $15.8 \mathrm{~b}$ & $13.2 \mathrm{~b}$ & 2.5 \\
\hline $\begin{array}{l}\text { Notification labels would be effective in decreasing the sale of } \\
\text { invasive plants }\end{array}$ & $8.8 \mathrm{~b}$ & $9.6 \mathrm{~b}$ & $24.6 \mathrm{a}$ & $31.6 \mathrm{a}$ & $25.4 \mathrm{a}$ & 3.6 \\
\hline \multicolumn{7}{|l|}{ Marketing alternatives to invasive plants } \\
\hline $\begin{array}{l}\text { Willing to distribute written information on noninvasive alternatives } \\
\text { to customers }\end{array}$ & $5.3 \mathrm{~d}$ & $9.6 \mathrm{~cd}$ & $17.5 \mathrm{bc}$ & $29.8 \mathrm{ab}$ & $37.7 \mathrm{a}$ & 3.9 \\
\hline Willing to create displays to emphasize noninvasive alternatives & $8.1 \mathrm{~b}$ & $7.2 \mathrm{~b}$ & $27.0 \mathrm{a}$ & $30.6 \mathrm{a}$ & $27.0 \mathrm{a}$ & 3.6 \\
\hline $\begin{array}{l}\text { Willing to emphasize noninvasive alternatives if consumer } \\
\text { preferences were known }\end{array}$ & $1.8 \mathrm{~b}$ & $4.4 \mathrm{~b}$ & $4.4 \mathrm{~b}$ & $44.2 \mathrm{a}$ & $45.1 \mathrm{a}$ & 4.3 \\
\hline $\begin{array}{l}\text { Native plants should be favored over noninvasive nonnative plants } \\
\text { as alternatives }\end{array}$ & $13.3 \mathrm{~b}$ & $16.8 \mathrm{~b}$ & $15.9 \mathrm{~b}$ & $19.5 \mathrm{ab}$ & $34.5 \mathrm{a}$ & 3.5 \\
\hline $\begin{array}{l}\text { Marketing alternative plants would decrease the sale of invasive plants } \\
\text { Taxing invasive plants }\end{array}$ & $0 \mathrm{c}$ & $3.5 \mathrm{bc}$ & $11.5 \mathrm{~b}$ & $46.0 \mathrm{a}$ & $38.9 \mathrm{a}$ & 4.2 \\
\hline Support an extra tax applied when plants are sold & $52.3 \mathrm{a}$ & $11.7 \mathrm{bc}$ & $18.9 \mathrm{~b}$ & $6.3 \mathrm{c}$ & $10.8 \mathrm{bc}$ & 2.1 \\
\hline Favor a tax when proceeds combat invasive plants and support research & $37.8 \mathrm{a}$ & $10.8 \mathrm{c}$ & $11.7 \mathrm{bc}$ & $14.4 \mathrm{bc}$ & $25.2 \mathrm{ab}$ & 2.8 \\
\hline Taxation would be effective in decreasing the sale of invasive plants & $43.2 \mathrm{a}$ & $12.6 \mathrm{~b}$ & $18.9 \mathrm{~b}$ & $11.7 \mathrm{~b}$ & $13.5 \mathrm{~b}$ & 2.4 \\
\hline \multicolumn{7}{|l|}{ Sterile genetically altered plants } \\
\hline Encourage research to create sterile cultivars of important invasive plants & $6.2 \mathrm{c}$ & $1.8 \mathrm{c}$ & $13.3 \mathrm{c}$ & $29.2 \mathrm{~b}$ & $49.6 \mathrm{a}$ & 4.1 \\
\hline $\begin{array}{l}\text { Would sell sterile genetically altered forms of invasive plants even if } \\
\text { more expensive }\end{array}$ & $8.8 \mathrm{~b}$ & $4.4 \mathrm{~b}$ & $15.0 \mathrm{~b}$ & $33.6 \mathrm{a}$ & $38.1 \mathrm{a}$ & 3.9 \\
\hline Availability of sterile cultivars would decrease the sale of invasive plants & $9.0 \mathrm{bc}$ & $1.8 \mathrm{c}$ & $21.6 \mathrm{ab}$ & $34.2 \mathrm{a}$ & $33.3 \mathrm{a}$ & 3.8 \\
\hline
\end{tabular}

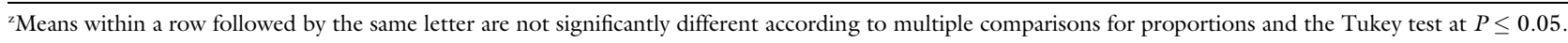

reservations about a program to label potentially invasive plants.

Reichard and White (2001) found that almost all respondents in their consumer survey said that they were "not at all" to "somewhat" likely to buy a plant labeled as invasive. In addition, the majority of CNLA members believed invasive plant notification labels would be effective in reducing the sale of invasive plants (Table 5). Labeling plants as invasive deserves serious consideration as a control measure, because there is minimal industry objection to this practice and because both consumers and producers believe it will help to reduce invasive plant sales and use.

Noninvasive plant alternaTIVES. Use of noninvasive alternatives to invasive plants is another option for controlling the sale of invasive plants, but for this control method to be successful, consumers must be educated about alternative species. At least $67.5 \%$ of CNLA members were willing to distribute written information to customers or create displays that emphasized alternatives to invasive plants, whereas only $14.9 \%$ expressed an unwillingness to do so (Table 5). Hall (2000) noted that $81 \%$ of respondents in her survey would distribute or already distribute educational pamphlets, whereas only $6 \%$ would not. The same survey found that only $13 \%$ of respondents were unwilling to put up signs suggesting alternatives to invasive plants. The nursery and landscape industries are clearly willing to participate in consumer education about noninvasive alternative species. One concern for growers and retailers who choose to promote noninvasive alternative 
species is the lack of knowledge about which alternative plants have the greatest consumer appeal and are likely to be the most profitable. Eighty-nine percent of CNLA respondents said that they would agree or strongly agree to emphasize alternatives if consumer preferences for alternatives were known (Table 5). Programs designed to reduce invasive plant use by promoting noninvasive alternative plants should determine consumer preferences for alternative species as part of the effort to maximize success.

There has been general disagreement about whether noninvasive alternative plants should be limited to native species or can be expanded to include nonnative species as well (Harrington et al., 2003). When asked about favoring native plants over exotic plants as alternatives to invasive plants, $53.7 \%$ of CNLA members agreed or strongly agreed that native plants should be favored (Table 5). However, $30.1 \%$ of the respondents were opposed to emphasizing native species and felt that exotic species should be included as well. Preference for native only or native plus exotic noninvasive species appears to be a personal choice and it may be difficult to reach consensus on this subject. There does seem to be industry consensus that marketing alternatives would be an effective way to reduce the sale of invasive plants, because $84.9 \%$ of CNLA members agreed or strongly agreed with the statement (Table 5).

Taxation. There was little support for taxation of invasive plants among CNLA members. Sixty-four percent of respondents did not support a tax on invasive plants at the point of sale and only $17.1 \%$ supported such a tax (Table 5). Support for a tax increased to $39.6 \%$ if tax proceeds were used to fund programs to combat invasive plants and support invasive plant research, but a large percentage of respondents (over $48 \%$ ) were still opposed to taxation. Relatively few CNLA members $(25.2 \%)$ felt that a tax on invasive plants would be an effective way to reduce the sale of invasive plants (Table 5). When Hall (2000) asked participants in her survey about donating a small percentage of their profits to research on invasive plants and their alternatives, only $11 \%$ answered positively and approximately half responded with a "maybe." Many respondents said they would require more information before making the investment and worried about the money actually going to the cause that they intended. Taxation of invasive plant sales does not seem to be a particularly viable approach for decreasing invasive plant sales.

Genetically altered sterile CULTIVARS. In contrast to opinions on taxation, our survey revealed a favorable response for the use of genetically altered sterile cultivars of invasive plants. Research to create sterile cultivars was encouraged by nearly $80 \%$ of respondents (Table 5 ). Only $13.2 \%$ of respondents were unwilling to sell genetically altered sterile cultivars of invasive plants, whereas $71.7 \%$ of the respondents were willing to sell these plants even if their production costs were higher (Table 5 ). A majority $(67.5 \%)$ of the respondents thought that genetically altered sterile plants would be an effective way to decrease the sale of invasive plants. Recent survey work determined that consumers would be interested and willing to purchase alternative plants that have been genetically engineered or bred to be seedless (Kelley et al., 2006). Furthermore, they would even be willing to pay more for a plant that had been tested to determine its invasiveness before being offered for sale. Acceptance of genetically modified sterile plants by both producers and consumers suggests that development of sterile plants should be pursued as an effective method of reducing the sale and use of invasive species.

\section{Conclusions}

CNLA members were asked to rank their preference for different approaches to reducing invasive plant sales to determine which ones have the greatest potential for adoption by the nursery and landscape industries (Table 6). Approaches that focused on "marketing noninvasive alternatives" and "sterile genetically altered invasive plants" received the greatest support from respondents. "Invasive plant notification labels" ranked next in acceptability, but responses were spread evenly from "most favorable" to intermediate rankings indicating less enthusiastic support for this approach. Nursery professionals did not feel strongly for or against "environmentally friendly" classification as a means of controlling invasive plant sale or use. Over $75 \%$ of respondents gave this solution middle rankings of 2,3 , or 4 . Least acceptable by a substantial margin was "taxation," which received a mean rank of 5.0 (unfavorable). Nearly $80 \%$ of respondents placed taxation in the two highest ranking categories (unfavorable) and nearly $50 \%$ placed it in the highest category of least favorable. "Statewide bans" was also not ranked as a desirable solution to invasive plants, receiving a mean rank of 4.1. However, response to "statewide bans" appears to be dichotomous with

Table 6. Connecticut Nursery and Landscape Association member ranking of various proposed methods for handling the sale of ornamentally important invasive plants.

\begin{tabular}{|c|c|c|c|c|c|c|c|}
\hline \multirow[b]{2}{*}{ Method } & \multicolumn{6}{|c|}{ Respondents selecting each rank (\%) } & \multirow[b]{2}{*}{$\begin{array}{c}\text { Mean } \\
\operatorname{rank} \pm S E\end{array}$} \\
\hline & $\begin{array}{c}\text { Most favorable } \\
1\end{array}$ & 2 & 3 & 4 & 5 & $\begin{array}{c}\text { Least favorable } \\
6\end{array}$ & \\
\hline Marketing noninvasive alternatives & $16.7{b c^{z}}^{2}$ & $40.5 \mathrm{a}$ & $25.0 \mathrm{ab}$ & $10.7 \mathrm{bcd}$ & $6.0 \mathrm{~cd}$ & $1.2 \mathrm{~d}$ & $2.5 \pm 0.1$ \\
\hline Sterile genetically altered invasive plants & $34.5 \mathrm{a}$ & $11.9 \mathrm{~b}$ & $11.9 \mathrm{~b}$ & $22.6 \mathrm{ab}$ & $7.1 \mathrm{~b}$ & $11.9 \mathrm{~b}$ & $2.9 \pm 0.2$ \\
\hline Invasive plant notification labels & $19.0 \mathrm{a}$ & $15.5 \mathrm{ab}$ & $26.2 \mathrm{a}$ & $23.8 \mathrm{a}$ & $10.7 \mathrm{ab}$ & $4.8 \mathrm{~b}$ & $3.1 \pm 0.2$ \\
\hline "Environmentally friendly" classification & $2.4 \mathrm{c}$ & $21.4 \mathrm{a}$ & 29.8 a & $25.0 \mathrm{a}$ & $16.7 \mathrm{ab}$ & $4.8 \mathrm{bc}$ & $3.5 \pm 0.1$ \\
\hline
\end{tabular}

${ }^{\mathrm{z}}$ Means within a row followed by the same letter are not significantly different according to multiple comparisons for proportions and the Tukey test at $P \leq 0.05$. 
many people viewing it as an undesirable approach and some others supporting it ardently. Few people seem to be undecided about their opinion on plant bans.

Future effective solutions to invasive ornamental plants will undoubtedly enlist the support of the nursery and landscape industry. Efforts will need to focus on consumer education, noninvasive alternative plants, and development of sterile forms of popular plants. Research efforts should address consumer preference for alternative species so growers can efficiently shift production away from popular invasives and toward alternatives that have known market appeal or promote underused alternatives. Education must continue to inform consumers about plants that are invasive, promote acceptable noninvasive alternatives, and also work to alleviate any unwarranted concerns about genetically altered sterile forms of plants. Nursery and landscape professionals continue to expand their understanding of the complex issues surrounding invasive ornamental plants. They are increasingly willing to participate in solutions to invasive ornamental plants, but clearly feel that some approaches are more acceptable than others.

\section{Literature cited}

American Nurseryman. 1999. Invasives roundtable. Amer. Nurseryman 190:54-77.

Anisko, T. and U. Im. 2001. Beware of butterfly bush. Amer. Nurseryman 194: 46-49.

Baskin, Y. 2002. The greening of horticulture: New codes of conduct aim to curb invasive plants. Bioscience 52:464-471.

Bell, C.E., C.A. Whilen, and A.E. Stanfon. 2003. Invasive plants of horticultural origin. HortScience 38:14-16.

Bir, R.E. 2000. Invasive plants and the nursery industry. Comb. Proc. Intl. Plant Prop. Soc. 50:490-492.

Bossard, C.C., J.M. Randall, and M.C. Horshovsky. 2000. Invasive plants of California's wildlands. Univ. of California Press, Berkeley.
Brand, M.H. and R.L. Leonard. 2001. Consumer product and service preferences related to landscape retailing. HortScience 36:1111-1116.

Connecticut Invasive Plants Council. 2004. Connecticut invasive plant list, Public Act PA 03-136. 25 Aug. 2006. <http://www.hort.uconn.edu/cipwg/ invPlantCT05.pdf>

Ehrenfeld, J.G., P. Kourtev, and W. Huang. 2001. Changes in soil functions following invasions of exotic understory plants in deciduous, forests. Ecol. Appl. 11:1287-1300.

Gordon, D.R. 1998. Effects of invasive, non-indigenous plant species on ecosystem processes: Lessons from Florida. Ecol. Appl. 8:975-989.

Hall, M. 2000. IPlants: Invasive plants and the nursery industry. 25 Aug. 2006. <http://www.brown.edu/Research/ Studies_Theses/full9900/mhall/ IPlants/Iplants_Frames.html>.

Harrington, R.A., R. Kujawski, and H.D.P. Ryan. 2003. Invasive plants and the green industry. J. Arboriculture 29:42-48.

Heneghan, L., C. Clay, and C. Brundage. 2002. Rapid decomposition of buckthorn litter may change soil nutrient status. Ecol. Restoration 20:108-111.

Kelley, K.M., J.R. Conklin, J.C. Sellmer, and R.M. Bates. 2006. Invasive plant species: Results of a consumer awareness, knowledge and expectations survey conducted in Pennsylvania. J. Environ. Hort. 24:53-58.

Lehrer, J.M., M.H. Brand, and J.D. Lubell. 2006. Four cultivars of japanese barberry demonstrate differential reproductive potential under landscape conditions. HortScience 41:762-767.

Likert, R. 1932. A technique for the measurement of attitudes. Arch. Psychol. 140:5-55.

Massachusetts Department of Agricultural Resources. 2006. Massachusetts prohibited plant list. 25 Aug. 2006. <http://www.mass.gov/agr/farmproducts/ proposed_prohibited_plant_list_v12-1205.htm>.

Miller, T.I. 2005. The great invasives debate. Digger 49:39-45.

Morin, N. 1999. Solving the invasive plant problem. Public Garden 14:16-17.
New Hampshire Department of Agriculture, Markets and Food. 2004. Chapter agr 3800 invasive species statutory authority: RSA 430:51-55, part agr 3801 invasive species part agr $3802 \mathrm{NH}$ prohibited invasive species. 25 Aug. 2006. <http://agriculture.nh.gov/divisions/ plant_industry/documents/Rules_8.pdf > .

Pimentel, D., L. Lach, R. Zuniga, and D. Morrison. 2000. Environmental and economic costs of nonindigenous species in the United States. Bioscience 50:53-65.

Pooler, M.R., R. Dix, and J. Feely. 2002. Interspecific hybridizations between the native bittersweet, Celastrus scandens, and the introduced invasive species, C. orbiculatus. Southeastern Naturalist 1:69-76.

Randall, J.M. and J. Marinelli. 1996. Invasive plants: Weeds of the global garden. Brooklyn Botanic Garden, N.Y.

Reichard, S.H. and P. White. 2001. Horticulture as a pathway of invasive plant introductions in the United States. Bioscience 51:103-113.

Tallamy, D. 2001. Where have all the birds gone? Garden Check 2001/7. 6 Apr. 2003. <http://ag.udel.edu/communications/garden check/2001/7/ birds.htm>.

U.S. Department of Agriculture. 2005. Floriculture and nursery crops outlook. 25 Aug. 2006. <http://www.ers.usda.gov/ Publications/flo/Sep05/FLO04.pdf>

Vitousek, P., C.M. D'Antonio, L.L. Loope, and R. Westbrooks. 1996. Biological invasion as global environmental change. Amer. Scientist 84:468-478.

Webb, S.L., G. Dwyer, C.K. Kaunzinger, and P.H. Wyckoff. 2000. The myth of the resilient forest: Case study of the invasive Norway maple (Acer platanoides). Rhodora 102:332-354.

Wilcove, D.S., D. Rothstein, J. Dubow, A. Phillips, and E. Losos. 1998. Quantifying threats to imperiled species in the United States. Bioscience 48:607-615.

Williams, R.H. and W.G. LeBlanc. 1995. Pairwise comparisons among proportions. Educ. Psychol. Meas. 55:445-447.

Woods, K.D. 1993. Effects of invasion by Lonicera tatarica $\mathrm{L}$. on herbs and tree seedlings in four New England forests. Amer. Midlands Naturalist 130:62-74. 